\title{
Retrospective Study of 114 Free Flaps for Head and Neck Oncological Reconstruction in a Portuguese Tertiary Cancer Center
}

\author{
Avaliação Retrospetiva da Reconstrução Oncológica da Cabeça \\ e Pescoço com 114 Retalhos Livres num Centro Oncológico \\ Terciário Português
}

\author{
Andreia SILVA ${ }^{1}$, Patrícia CAIXEIRINHO ${ }^{2}$, Miguel VILARES ${ }^{3}$, Carina SEMEDO ${ }^{3}$, Mariluz MARTINS ${ }^{3}$, Carlos ZAGALO ${ }^{4}$, \\ Diogo CASAL $\square^{5}$ \\ Acta Med Port 2022 Mar;35(3):192-200 - https://doi.org/10.20344/amp.13734
}

\section{ABSTRACT}

Introduction: The Portuguese experience in microsurgical reconstruction of the head and neck after oncological surgery is scantly described. The primary aim of this study was to characterize the use of microvascular reconstruction after head and neck tumor resection in a Portuguese tertiary oncological center

Material and Methods: The authors retrospectively evaluated 114 microvascular free flap procedures performed for head and neck reconstruction after oncological resection in a department of Head and Neck Surgery of a Portuguese tertiary oncological center. Patients were operated on from January 2012 to May 2018. Data on patient demographic features, tumour characteristics, perioperative complications, postoperative aesthetic and functional results, survival time and time to recurrence were extracted.

Results: Most tumours mandating microsurgical reconstruction were mucosal squamous cell carcinomas (85\%) and were located in the oral region (95.6\%). Around $45 \%$ of the patients had a T4a tumour and $30 \%$ a T2 tumour. Cervical metastases were present in $45.6 \%$ of the cases. The radial forearm flap and the fibular flap were the most commonly used microsurgical reconstructive options ( $58 \%$ and $41 \%$, respectively). More than $80 \%$ of patients had no post-operative complications. Partial necrosis of the flap occurred in $6.1 \%$ of patients, while total flap necrosis occurred in $3.5 \%$ of cases. Aesthetic and functional results were considered at least satisfactory in all patients in which the flaps survived.

Conclusion: Microvascular reconstruction seems like a reliable treatment option in head and neck oncological surgery at our institution.

Keywords: Free Tissue Flaps; Head and Neck Neoplasms/surgery; Postoperative Complications; Reconstructive Surgical Procedures

\section{RESUMO}

Introdução: A experiência portuguesa na reconstrução microcirúrgica da cabeça e pescoço após cirurgia oncológica está escassamente descrita. O objectivo deste estudo foi caracterizar a reconstrução microcirúrgica da cabeça e pescoço num centro de referência terciário português.

Material e Métodos: Os autores avaliaram retrospetivamente 114 procedimentos de retalhos livres microvasculares realizados para reconstrução de cabeça e pescoço após ressecção oncológica num departamento de Cirurgia de Cabeça e Pescoço de um centro oncológico terciário português. Os doentes foram operados no período de janeiro de 2012 a maio de 2018. Foram registadas as características demográficas dos doentes, as características do tumor, as complicações peri-operatórias, os resultados estéticos e funcionais pós-operatórios, bem como o tempo de sobrevida e o tempo de recorrência.

Resultados: A maior parte dos tumores estava localizada na região oral (95,6\%), sendo o carcinoma de células escamosas o tipo histológico mais frequente. Os retalhos antebraquial radial e fibular foram as opções reconstrutivas mais usadas (58\% e $41 \%$, respetivamente). Mais de $80 \%$ dos doentes não apresentaram complicações pós-operatórias. A necrose parcial do retalho ocorreu em sete doentes $(6,1 \%)$, enquanto a necrose total do retalho ocorreu em apenas quatro casos $(3,5 \%)$. Os resultados estéticos e funcionais foram considerados pelo menos satisfatórios em todos os doentes em que os retalhos sobreviveram.

Conclusão: A reconstrução microvascular parece ser uma opção fiável e eficaz no âmbito da cirurgia oncológica de cabeça e pescoço na nossa instituição.

Palavras-chave: Complicações Pós-Operatórias; Neoplasias de Cabeça e Pescoço/cirurgia; Procedimentos Cirúrgicos Reconstrutivos; Retalhos de Tecido Biológico

\section{INTRODUCTION}

Head and neck cancers represent the sixth most common malignant neoplasms in most developed countries. ${ }^{1}$ Even today, reconstruction of major defects after head and neck oncological resection continues to be a vexing

problem. ${ }^{2-8}$ The literature is unanimous in stating that head and neck cancer has a major negative impact on patients' quality of life and socio-economic status. ${ }^{9,10}$

The head and neck regions are anatomically and

1. Maxillofacial Surgery Department. Centro Hospitalar Universitário de Lisboa Central. Lisboa. Portugal.

2. Stomatology Department. Centro Hospitalar Universitário de Lisboa Central. Lisboa. Portugal.

3. Head and Neck Department. Portuguese Institute of Oncology. Lisbon. Portugal.

4. Centro de Investigação Interdisciplinar Egas Moniz. Monte de Caparica. Portugal.

5. Plastic and Reconstructive Surgery Department. Centro Hospitalar Universitário de Lisboa Central. NOVA Medical School. Lisbon. Portugal.

$\triangle$ Autor correspondente: Diogo Casal. diogo bogalhao@yahoo.co.uk

Recebido: 16 de março de 2020 - Aceite: 14 de maio de 2021 - First published: 28 de setembro de 2021 - Online issue published: 02 de março de 2022

Copyright $\odot$ Ordem dos Médicos 2022 
histologically complex. Most malignant neoplasms in these regions arise from the mucosa of the upper aerodigestive tract, including the oral cavity, pharynx, larynx, nasal cavity, and sinuses. Other locations such as the salivary glands, thyroid, and parathyroid glands, soft tissue, bone, and skin are less frequent origins. The most common malignant neoplasms of the head and neck consist of squamous cell carcinoma and papillary thyroid cancer. Salivary gland cancers and sarcomas of the soft tissue and bone are less frequent. ${ }^{5,11-13}$

Although surgery has been the mainstay of therapy for these neoplasms, it can result in severe defects associated with aesthetical and functional impairment. Functional deficits range from difficulties in speech and swallowing to changes in eyelid function, oral competence, and maintenance of nasal and oral permeability. ${ }^{5,8}$ Speech and swallowing impairment are particularly troublesome and are related with tumor dimension. In this context, tumors of the tongue and floor of the mouth have a poorer functional outcome. ${ }^{8}$

Reconstructive solutions are usually thought of in terms of aesthetic and functional units which are rebuilt starting from the underlying bony framework, and subsequently replacing the overlying integument. A spectrum of reconstructive options exists, ranging from allowing wounds to heal by secondary intention or primary closure of relatively small defects, to extensive reconstruction, involving pedicled and/ or microvascular free flaps. ${ }^{14-18}$ The appropriate option depends on the location and type of the defect, the patient's overall health, available donor sites, the status of the tissue adjacent to the defect (taking into consideration, for example, prior irradiation, infection and/or surgery), and on the function of the area to be reconstructed. Not only must the reconstructive surgeon choose which option is best suited for a given defect, but also secondary and tertiary options should be planned in case of flap failure or recurrent disease..$^{8,19}$

Microvascular free flaps are increasingly performed worldwide in head and neck surgery departments since the 1970s, and are associated with better functional and aesthetical outcomes compared to those of more conservative treatments, while ensuring high flap survival rates. ${ }^{20,21}$ They are reportedly reliable in achieving successful reconstruction of the head and neck regions, with the incidence of postoperative complications being largely related with preoperative comorbidities. ${ }^{22}$ According to most authors, surgical re-exploration due to vascular insufficiency is necessary in less than $10 \%$ of the flaps, and necrosis of the flap occurs in only about $5 \%$ of cases. The American Society of Anesthesiology (ASA) class and age are considered the best predictors of post-operative morbidity. ${ }^{23}$ However, as indications are progressively being widened, even advanced age has been questioned as an indicator of increased risk of perioperative complications, such as flap failure. ${ }^{24,25}$ In fact, there are series of selected patients over 90 years old that are subjected to head and neck microsurgical reconstruction with no apparent increase in complications. ${ }^{26}$ Prior ra- diotherapy, on the other hand, seems to have a particularly deleterious effect on free flap survival in the realm of head and neck oncological reconstruction. ${ }^{27}$ Similarly, oral cavity and pharyngeal free flap reconstruction have also been associated with a greater complication rate. ${ }^{28}$

Surprisingly, despite this vast international experience, the information regarding the Portuguese reality in head and neck microvascular reconstruction after oncological resection is scant at best. ${ }^{29-34}$

The primary aim of this study was to characterize the use of microvascular reconstruction after head and neck tumor resection in a Portuguese tertiary oncological center over an extended period of time. Secondarily, the authors evaluated the influence of risk factors, such as tumor staging and therapy choice, in locoregional recurrence and patient survival.

\section{MATERIAL AND METHODS}

The authors retrospectively reviewed the clinical records of all patients subjected to reconstruction of the head and neck regions after tumour ablation in the department of Head and Neck Surgery of Instituto Português de Oncologia de Lisboa Francisco Gentil (Lisbon, Portugal), between January 2012 and May 2018. Only those patients with at least two post-operative follow-up visits were included in the study.

Data on the following variables were extracted: demographic features, co-morbidities, current immunosuppression status, antiaggregation, anticoagulation, smoking and alcohol drinking habits, clinical, histological and staging features of the primary tumour, reconstructive option, concomitant neck dissection, immediate and/or postoperative complications (occurring during and after hospital discharge, respectively), ${ }^{35}$ need of adjuvant chemotherapy and/or radiotherapy, presence of recurrence and time to recurrence. Functional and aesthetical results were qualitatively evaluated by the surgical team as: poor, fair, good, or excellent. The authors used the seventh edition of the American Joint Committee on Cancer TNM Staging of Head and Neck Cancer and Neck Dissection Classification for tumor staging and neck dissection classification. ${ }^{36}$

The authors declare that they acted in accordance with the regulations established by the Ethics Committee of their institution and in accordance with the Helsinki Declaration of the World Medical Association that was updated in 2013. ${ }^{37}$ Moreover, the authors confirm that they followed their institution's regulations on publishing data. Being a retrospective descriptive study, no formal ethical committee review was required. ${ }^{38}$

\section{Statistical analysis}

The Statistical Package for the Social Sciences (IBM Corp. Released 2011. IBM SPSS Statistics for Windows, Version 23.0. Armonk, NY: IBM Corp.) was used for statistical analysis. A significance level of 0.05 was considered. Values were expressed as means and standard deviation (SD) for continuous variables and as percentages for 
categorical variables. We evaluated frequency differences using the chi-square test. The Yates's correction for continuity was applied in order not to overestimate chi-square test values. Differences between means were evaluated using the Student's $t$-test. The association between specific characteristics and the recurrence of squamous cell carcinoma after surgery was assessed via a logistic regression approach using the Firth procedure. ${ }^{39}$ For odds ratios (OR), $95 \%$ confidence intervals $(\mathrm{Cl})$ were used.

\section{RESULTS}

The authors identified 114 patients subjected to head and neck reconstruction using free flaps (Table 1). In each case, the choice of a microsurgical reconstruction was made by the surgical team based on the potential superiority of this option compared to more traditional techniques. Most patients were male ( $n=84 ; 74 \%)$. The average age of patients at the time of surgery was $54.0 \pm 10.6$ years. Mean follow-up time was $43.2 \pm 3.1$ months, ranging from 12 to 85 months. Almost half of the patients (44\%) were considered healthy prior to the diagnosis of neoplasia. Interestingly, the single most frequent pre-operative comorbidity was a prior malignant neoplasm diagnosis in another location, which was present in $27 \%$ of patients. In $15 \%$ of all patients there was a history of a previous squamous cell carcinoma of the lip, oral cavity or nasal-oro-hypopharynx regions. These latter patients had been subjected to prior surgery in the head and neck region. Hypertension was present in 16\% and asthma or chronic obstructive pulmonary disease (COPD) in $8 \%$ of the cases (Table 1 ).

Around a quarter of patients were immunosuppressed. and the most important causes were identified as neoadjuvant chemoradiotherapy $(7.9 \%)$, neoadjuvant radiotherapy $(7.0 \%)$, diabetes mellitus $(3.5 \%)$, corticosteroid therapy (2.6\%) and HIV infection (1.8\%) (Table 1). However, this was not considered an exclusion criteria to perform a microvascular free flap. Only $8 \%$ were anti-aggregated, and no patient was hypo-coagulated. Prior to the surgery, three quarters of the patients had a history of cigarette smoking, and around $60 \%$ reported regular alcohol consumption (Table 1).

Regarding the primary tumour histopathologic features, the most common tumour types were mucosal squamous cell carcinoma (85\%), and cutaneous squamous cell

Table 1 - Clinical data analysis of the patients who underwent microvascular free flap

\begin{tabular}{|c|c|}
\hline Variables & n (\%) \\
\hline \multicolumn{2}{|l|}{ Gender } \\
\hline Male & $84(73.7)$ \\
\hline Female & $30(26.3)$ \\
\hline Age (mean \pm standard deviation [years]) & $54.05 \pm 10.6$ \\
\hline \multicolumn{2}{|l|}{ Comorbidities } \\
\hline None & $50(43.9)$ \\
\hline Malignant neoplasm & $29(27.3)$ \\
\hline Squamous cell carcinoma of the lip, oral cavity or nasal-oro-hypopharynx region & $17(14.9)$ \\
\hline Other tumors, except the head and neck region & $6(5.3)$ \\
\hline Other carcinomas of head and neck region & $4(3.7)$ \\
\hline Lymphoproliferative disease & $2(1.8)$ \\
\hline Hypertension & $18(15.8)$ \\
\hline Asthma or Chronic obstructive pulmonary disease & $9(7.9)$ \\
\hline Other & $6(5.4)$ \\
\hline \multicolumn{2}{|l|}{ Immunosuppression } \\
\hline None & $86(75.4)$ \\
\hline Neoadjuvant chemoradiotherapy & $9(7.9)$ \\
\hline Neoadjuvant radiotherapy & $8(7.0)$ \\
\hline Diabetes mellitus & $4(3.5)$ \\
\hline Corticosteroid therapy & $3(2.6)$ \\
\hline HIV infection & $2(1.8)$ \\
\hline Other & $2(1.8)$ \\
\hline Antiaggregation & $9(7.9)$ \\
\hline Anticoagulation & $0(0.0)$ \\
\hline \multicolumn{2}{|l|}{ Consuming habits } \\
\hline Smoking & $85(74.6)$ \\
\hline Alcohol & $67(58.8)$ \\
\hline
\end{tabular}


carcinoma (4\%). The tongue and the floor of the mouth were the most frequent primary tumour sites (Table 2). Histologically, around $45 \%$ of the patients had a T4a tumour, and $30 \%$ a T2 tumour. The histopathological examination showed that cervical metastases were present in $45.6 \%$, whereas $46.5 \%$ presented a N0 neck staging. More than three quarters $(76 \%)$ possessed a moderate or an undifferentiated carcinoma (Table 3).

Concerning tumour histopathological features, ominous characteristics were present in around half of the patients and these were considered an indication for adjuvant chemotherapy. Amongst these negative histopathological characteristics, perineural invasion was present in $16.7 \%$, lymphovascular invasion in $14.0 \%$ and simultaneous invasion

Table 2 - Clinical and staging features of the primary tumour

\begin{tabular}{|c|c|}
\hline Variables & n $(\%)$ \\
\hline \multicolumn{2}{|l|}{ Site } \\
\hline Tongue & $36(31.6)$ \\
\hline Floor of the mouth & $27(23.7)$ \\
\hline Gum & $17(14.9)$ \\
\hline Retromolar trigone & $15(13.2)$ \\
\hline Mandible (intra-osseous) & $8(7.0)$ \\
\hline Skin & $5(4.4)$ \\
\hline Hard palate & $2(1.8)$ \\
\hline Other & $4(3.6)$ \\
\hline \multicolumn{2}{|l|}{ Histology } \\
\hline Squamous cell carcinoma of oral cavity & $97(85.1)$ \\
\hline Skin carcinoma & $4(3.5)$ \\
\hline Ameloblastoma & $3(2.6)$ \\
\hline Malignant odontogenic tumour & $3(2.6)$ \\
\hline Salivary gland carcinoma & $3(2.6)$ \\
\hline Melanoma & $2(1.8)$ \\
\hline Other & $2(1.8)$ \\
\hline \multicolumn{2}{|l|}{ Tumour staging } \\
\hline \multicolumn{2}{|l|}{$\mathrm{T}$} \\
\hline Not applicable ${ }^{a}$ & $8(7.0)$ \\
\hline Carcinoma in situ & $0(0.0)$ \\
\hline $\mathrm{T} 1$ & $9(7.9)$ \\
\hline $\mathrm{T} 2$ & $34(29.8)$ \\
\hline T3 & $11(9.6)$ \\
\hline $\mathrm{T} 4 \mathrm{a}$ & $52(45.6)$ \\
\hline \multicolumn{2}{|l|}{$\mathrm{N}$} \\
\hline Not applicable ${ }^{b}$ & $9(7.9)$ \\
\hline No & $53(46.5)$ \\
\hline $\mathrm{N} 1$ & $10(8.8)$ \\
\hline $\mathrm{N} 2 \mathrm{a}$ & $0(0.0)$ \\
\hline $\mathrm{N} 2 \mathrm{~b}$ & $34(29.8)$ \\
\hline $\mathrm{N} 2 \mathrm{C}$ & $8(7.0)$ \\
\hline M0 & $114(100)$ \\
\hline
\end{tabular}

of nerves and vessels in $14.0 \%$. Only $10.5 \%$ of patients had a tumour resection margin below $1 \mathrm{~mm}$ (Table 3).

As for the choice of free flap used for the oncological reconstruction, the radial antebrachial fasciocutaneous flap was used in $58 \%$ of patients, particularly when thin soft tissue was required to reconstruct the defect (Table 4). Fibular bone flaps were used in $41 \%$ of patients. The latter flap was especially useful to reconstruct subtotal segmental mandibular defects. Its thick cortical plates proved ideal to resist to mastication forces and allow a smooth posterior fixed oral rehabilitation. All flaps were connected to the recipient site with at least one arterial and two venous anastomoses.

In most cases, microvascular reconstruction was performed immediately after tumour removal in the same operative time $(89 \%)$. In less than $3 \%$, reconstruction was performed within one to two years after tumour extirpation, and in $4 \%$ microvascular reconstruction was deferred to at least five years after tumour ablation. Concerning concomitant neck dissection, 55\% had a unilateral modified radical dissection, $25 \%$ had a bilateral modified radical dissection and $11 \%$ did not have a neck dissection (Table 4).

In the postoperative period, free flap reconstruction patients were admitted to the intensive care unit for the first 24 to 48 hours. Even though more than $80 \%$ of the patients had an uneventful post-operative period, $11.4 \%$ experienced an immediate post-operative complication (psychomotor agitation, and poor flap vascularization). In the late postoperative period, there were four cases of tumour progression (3.5\%) with two cases culminating in patient death. Partial or total flap necrosis occurred only in seven $(6.1 \%)$ and four (3.5\%) cases, respectively. Fibula and radial forearm free flaps showed no significant differences in terms of viability. Patients with flap suffering $(9.6 \%)$ underwent microvascular

Table 3 - Histopathologic features of the primary tumour

\begin{tabular}{lc}
\hline Variables & $\mathbf{n}(\%)$ \\
\hline Histological differentiation $(\mathrm{G})$ & \\
Not applicable & $12(10.5)$ \\
G1 & $15(13.2)$ \\
G2 & $62(54.4)$ \\
G3 & $25(21.9)$
\end{tabular}

Negative histological characteristics

None

Perineural invasion

$19(16.7)$

Lymphovascular invasion

$16(14.0)$

Both

$16(14.0)$

Not applicable

$6(5.3)$

Histological margins

$\begin{array}{lc}\geq 5 \mathrm{~mm} & 48(42.1) \\ 1-4 \mathrm{~mm} & 52(45.6) \\ <1 \mathrm{~mm} & 12(10.5) \\ \text { Not applicable } & 2(1.8)\end{array}$

Histological differentiation of the tumour: G1 Well differentiated (low grade); G2 Moderately differentiated (intermediate grade); G3 Poorly differentiated (high grade) 
Table 4 - Surgical data

\begin{tabular}{lc}
\hline Variables & $\mathbf{n}(\%)$ \\
\hline Free flap & $47(41.2)$ \\
Fibula & $66(57.9)$ \\
Antebrachial & $1(0.9)$ \\
Other & $101(88.6)$ \\
Reconstructive surgery & $2(1.8)$ \\
Same operating time & $6(5.5)$ \\
$\leq 1$ year & $5(4.4)$ \\
$>1$ - 4 years & \\
$>5$ years & $13(11.4)$ \\
Neck dissection & $63(55.3)$ \\
No & $28(24.6)$ \\
Unilateral radical modified & $6(5.3)$ \\
Bilateral radical modified & $3(2.6)$ \\
Ipsilateral radical modified and contralateral supraomohyoid neck dissection & \\
Unilateral supraomohyoid neck dissection & \\
\hline
\end{tabular}

anastomosis revision and/or local surgical debridement. In cases of full-thickness flap necrosis, a contralateral free flap or local pedicled flap were used. There was no statistically significant association between flap failure and specific demographic or clinical features.

Aesthetic and functional results were considered at least satisfactory in all patients in which the flaps survived. Most patients were subjected to adjuvant therapy with either radiotherapy or a combination of chemotherapy and radiotherapy (Table 5). No flap complications were observed as a consequence of these treatments.

The degree of tumour histological differentiation was statistically different in males, smokers, as well as in patients with alcohol drinking habits: more $\mathrm{G} 2$ tumours (moderately differentiated) than $\mathrm{G} 1$ or $\mathrm{G} 3$ tumours (well differentiated and poorly differentiated, respectively) were observed in males $(67 \%$ vs $39 \% p=0.028)$, smokers $(68 \%$ vs $35 \% p$ $=0.004)$ and alcohol consumers $(69 \%$ vs $46 \%, p=0.016)$ (Table 6).

Female patients presented a lower incidence of smoking $(33.3 \%$ vs $89.3 \%, p<0.001)$ and alcohol drinking habits $(13.3 \%$ vs $75 \%, p<0.001)$ compared to male patients.

Table 5 - Postoperative period

\begin{tabular}{lc}
\hline Variables & $\mathbf{n}(\%)$ \\
\hline Postoperative complication & \\
None & $95(83.3)$ \\
Psychomotor agitation & $2(1.8)$ \\
Flap partial necrosis & $7(6.1)$ \\
Flap total necrosis & $4(3.5)$ \\
Progression of tumoral disease & $4(3.5)$ \\
Death & $2(1.8)$ \\
Adjuvant radiotherapy & $85(74.6)$ \\
Adjuvant chemoradiotherapy & $67(58.7)$ \\
\hline
\end{tabular}

Female patients had a lower tumour recurrence (30\%) compared to male patients $(40 \%)$, even though the difference was not statistically significant. Locoregional tumor recurrence was observed in $32.5 \%$ of patients, with the majority being diagnosed in the first 6 months after the oncological surgery $(18.4 \%)$. Afterwards, recurrences were increasingly rare $(7.9 \%$ between six to 12 months postoperatively, $5.3 \%$ from one to three years, and $0.9 \%$ after more than three years). In fact, most of recurrent cases were associated with the persistence of the primary tumor. Metastases were detected in only five cases (4.4\%).

Comparing patients' survival time or time to recurrence based on their surgical margins on histopathology examination ( $>5 \mathrm{~mm} ; 1-5 \mathrm{~mm} ;<1 \mathrm{~mm}$ ), there were no statistically significant differences $(p=0.143$ and $p=0.157$, respectively). Moreover, none of the tested characteristics (tumour margin size, $\mathrm{T}$ and $\mathrm{N}$ staging, and type of neck dissection) was associated with tumour recurrence (no recurrence versus any recurrence).

\section{DISCUSSION}

Although microsurgical reconstruction of the head and neck regions has been described for half a century, the inherent technical difficulty of the procedures has discouraged many large volume centres of adopting these techniques for the majority of patients. ${ }^{21}$ As far as the authors could determine, this is by far the largest series of microsurgical head and neck reconstruction after oncological surgery reported by a single tertiary centre in Portugal. ${ }^{29-34}$

As most authors, in our series two flaps were mainly used for microsurgical reconstruction: the fasciocutaneous radial antebrachial flap was used in $58 \%$ of patients when thin soft tissue was required, and a fibular bone flap was raised to reconstruct subtotal segmental mandibular defects. The thick cortex of this bone allows the insetting of reconstruction plates that are ideal to resist mastication forces 
Table 6 - Tumour histological differentiation by patient' characteristics

\begin{tabular}{|c|c|c|c|c|}
\hline \multicolumn{5}{|l|}{ Variables } \\
\hline Gender, n (\%) & G1 & G2 & G3 & $p$-value \\
\hline Female & $7(30.4)$ & $9(39.1)$ & $7(30.4)$ & \\
\hline Male & $8(10.1)$ & $53(67.1)$ & $18(22.8)$ & 0.028 \\
\hline \multicolumn{5}{|c|}{ Immunosuppression, n (\%) } \\
\hline No & $13(16.3)$ & $48(60.0)$ & $19(23.8)$ & \\
\hline Yes & $2(9.5)$ & $14(66.7)$ & $5(23.8)$ & 0.712 \\
\hline \multicolumn{5}{|c|}{ Smoking habits, n (\%) } \\
\hline No & $8(34.8)$ & $8(34.8)$ & $7(30.4)$ & \\
\hline Yes & $7(8.9)$ & $54(68.4)$ & $18(22.8)$ & 0.004 \\
\hline \multicolumn{5}{|c|}{ Alcohol consumption, n (\%) } \\
\hline No & $10(27.0)$ & $17(45.9)$ & $10(27.0)$ & \\
\hline Yes & $5(7.7)$ & $45(69.2)$ & $15(23.1)$ & 0.016 \\
\hline
\end{tabular}

Histological differentiation of the tumour: G1 Well differentiated (low grade); G2 Moderately differentiated (intermediate grade); G3 Poorly differentiated (high grade)

Frequency differences were evaluated using the chi-square test. The Yates's correction for continuity was applied.

and to permit a smooth posterior fixed oral rehabilitation..$^{40,41}$

The authors performed reconstructive surgery at the same time of tumour ablation in about $87 \%$ of the cases. In less than $3 \%$, the reconstruction was deferred to one to two years after removing the tumour and in about $4 \%$ only after five years of follow up. In the present series, tumour recurrence had no relationship with the timing of the microsurgical reconstructive procedure. These data vindicate those who defend immediate microsurgical reconstruction, in order to minimize functional and aesthetical limitations while ensuring oncological safety. ${ }^{41-43}$

Regarding neck dissection, a unilateral modified radical dissection was performed in $55 \%$ of the cases, a bilateral modified radical dissection in $25 \%$, and in $11 \%$ of the patients no neck dissection was done (benign tumours, in situ tumours and basal cell carcinomas). Even in T1 patients $(7.9 \%)$, with no clinical neck metastasis, a selective neck dissection was performed, that in conjunction with adjuvant radiotherapy has been shown to increase survival rate. ${ }^{11-13}$ The authors endorse the view that prophylactic neck dissections are warranted for clinically negative head and neck tumors that have a significant probability of having occult metastasis in the neck. ${ }^{44-46}$ In the case of large tumours mandating microsurgical reconstruction, as the ones described in this series, the authors do not regularly perform sentinel node biopsy, due to the risk of overlooking skip metastases. ${ }^{44}$

More than $80 \%$ of patients presented an eventful postoperative period. Flap partial and total necrosis only occurred in seven $(6.1 \%)$ and four $(3.5 \%)$ cases, respectively. These data lend support to the safety of microsurgical reconstruction in the realm of head and neck oncological reconstruction. $2,5,6,8,19,20,23,42$

Probably due to the small number of cases in which partial or total flap necrosis occurred, it was not possible to associate flap failure with specific demographic or clinical features in the present series. However, according to the literature, technical errors and certain pre-existing conditions are associated with a higher tendency to flap failure, namely alcohol abuse, radiotherapy and diabetes mellitus. ${ }^{6,7,47}$ Other characteristics, such as advanced age and gender, have not been linked to an increased risk of free flap failure. . $^{24,48-50}$ Nevertheless, the importance of meticulous attention to perioperative management of comorbidities, hemoglobin and albumin levels, anticoagulation, fluid and electrolytes, as well as flap monitoring cannot be overstated. ${ }^{47,48}$

It is known that negative histopathologic features can help to predict a higher tumour recurrence rate. Among those, extracapsular ganglion dissemination, perineural and vascular invasion, poor tumour differentiation and positive margins seem to be crucial to patient prognosis, and indicate whether a patient should be directed or not to adjuvant chemotherapy. ${ }^{51}$ Extranodal extension was introduced in the eight edition of the American Joint Committee on Cancer (AJCC) staging manual TNM staging for both clinical and pathologic $\mathrm{N}$ staging of tumours not associated with high-risk Human Papillomavirus. In fact, extranodal extension has been increasingly recognized as important independent prognostic factor. ${ }^{52}$ However, for the duration of most of this patient series the seventh edition of the AJCC TNM staging was in place, in which this variable was not explicitly included ${ }^{36}$ Therefore, the authors did not assess this variable in the present study. Further studies are warranted to evaluate if extranodal extension status has an impact on free flap reconstruction of the head and neck.

Half of patients had at least one negative histopathologic feature with perineural invasion being predominant $(14 \%)$. The authors observed that the degree of tumor histological differentiation was statistically different in smokers versus non-smokers, males versus females, as well as in patients with alcohol drinking habits (Table 6). Smoking habits and alcohol drinking habits were more prevalent in male patients, whereas tumour recurrence was less frequent in female patients, although this latter difference was not statistically significant.

It is known that histological margins in squamous cell carcinoma are the most important survival indicator. By following the National Comprehensive Cancer Network ${ }^{\circledR}$ 
guidelines, the authors considered a free margin if the resected specimen included a cuff of at least $5 \mathrm{~mm}$ of noninvaded tissue, even when accounting for tumour shrinkage as result of histopathology preparation. ${ }^{53}$ In this context, free margins were obtained in almost half of the patients. The authors feel that this finding was due to the advanced stage of many of the tumours. In fact, around $45 \%$ of the patients had a T4a tumour and $45.6 \%$ cervical metastasis at the time of surgery. These data highlight the importance of an early diagnosis, in order to prevent growth and histological mutations, which carry a worse prognosis. ${ }^{19}$

It is widely accepted that free flap reconstruction does not preclude adjuvant therapy. ${ }^{2,24}$ In the present series, the majority of patients $(74.6 \%)$ were treated with radiotherapy, and $58.7 \%$ with combined chemoradiotherapy. No significant flap complications were noted after these treatments, which lends further support to the use of free flaps in the realm of head and neck oncological resection.

It is widely accepted that squamous cell carcinoma is a generalized mucosal disease. ${ }^{54}$ Long-term follow up of squamous cell carcinoma is mandatory and distinguishing a new primary tumour from a persistence or recurrence of the same tumour is paramount in order to ensure an adequate treatment. ${ }^{54,55}$ The authors observed locoregional tumor recurrence in $32.4 \%$ of the patients with the majority having a diagnosis in the first six months post-operatively. In fact, most of these cases probably resulted from the persistence of the primary tumor. ${ }^{56}$ Remote metastases were found in only five cases (3.55\%).

These data are well aligned with those generally described in the literature for tertiary oncological centers. It is well established that complete resection of malignant tumors in the head region is frequently more difficult than that of other anatomical regions, due to the high density of functional and aesthetically relevant structures in the former regions. ${ }^{57-59}$

The authors observed that neither the survival time nor the time until recurrence were statistically different according to surgical margins. Similarly, the authors did not associate any of the tested characteristics (surgical margins, $T$ and $\mathrm{N}$ staging or neck dissection) with recurrence. However, the prognostic value of TNM staging in head and neck cancer has been thoroughly documented. The lack of association in the present study is probably the result of the relatively small number of patients, and of the limited follow up time.

This study provides a single institution and retrospective analysis with cumulative surgical experience over eight years. During this period, different surgeons intervened, but only one senior surgeon (M.V) executed the microvascular anastomoses, which could be a potential source of bias. Further studies are warranted to confirm or rebut these findings in smaller institutions, and in places where surgeries are performed more often by junior doctors.

Another potential limitation of this study is that the experience reported refers exclusively to that of the Head and Neck Surgery Department of Instituto Português de Oncologia de Lisboa Francisco Gentil (Lisbon, Portugal). It does not include the experience of other Departments of this institution namely of the Otorhinolaryngology and Plastic and Reconstructive Surgery Departments, that also perform free flap reconstruction on a regular basis. Hence, 95.6\% of the oncological defects mandating microvascular reconstruction in the present series were located in the oral region. Future studies based on prospective hospital wide or even nationwide registries may allow the inclusion of data pertaining to different anatomical regions and various medical specialties. ${ }^{60}$

\section{CONCLUSION}

The authors believe that this sizeable experience of microvascular reconstruction seems to be a reliable treatment option in the context of head and neck oncological reconstructive surgery in a Portuguese tertiary centre. In this realm, microvascular flaps provided adequate aesthetic and functional results, with no compromise of the start of adjuvant therapy.

\section{ACKNOWLEDGEMENTS}

The authors wish to thank Dr. Jorge Rosa Santos, for his support and assistance through the implementation of the free flap surgery program at their institution.

\section{AUTHORS CONTRIBUTION}

AS, PC: Conception and design of the work. Acquisition, analysis, and interpretation of data for the work. Drafting.

MV: Conception and design of the work. Acquisition, analysis, and interpretation of data for the work. Drafting the work and revising it critically as far as format and contents are concerned.

CS, MM: Conception and design of the work. Analysis and interpretation of data for the work. Critical review of the work as far as format and contents are concerned.

CZ, DC: Conception or design of the work. Analysis and interpretation of data for the work. Drafting.

\section{PROTECTION OF HUMANS AND ANIMALS}

The authors declare that the procedures were followed according to the regulations established by the Clinical Research and Ethics Committee and to the Helsinki Declaration of the World Medical Association updated in 2013.

\section{DATA CONFIDENCIALITY}

The authors declare having followed the protocols in use at their working centre regarding patients' data publication.

\section{COMPETING INTERESTS}

The authors have declared that no competing interests exist.

\section{FUNDING SOURCES}

This research received no specific grant from any funding agency in the public, commercial, or not-for-profit sectors. 


\section{REFERENCES}

1. Marur S, Forastiere A. Head and neck squamous cell carcinoma: update on epidemiology, diagnosis, and treatment. Mayo Clin Proc. 2016;91:386-96.

2. Gabrysz-Forget F, Tabet P, Rahal A, Bissada E, Christopoulos A, Ayad T. Free versus pedicled flaps for reconstruction of head and neck cancer defects: a systematic review. J Otolaryngol Head Neck Surg. 2019;48:13.

3. Sparkman DM, Simmons MR, Patil YJ. Subjective morbidity following fibular free flap reconstruction in head and neck cancer patients. J Laryngol Otol. 2018;132:729-33.

4. Rastogi S, Sharma A, Choudhury R, Tripathi S, Al Wayli H, Amrithraj A, et al. Is superselective neck dissection safer than supraomohyoid neck dissection for oral carcinoma patients with no neck in terms of shoulder morbidity and recurrence rate? J Oral Maxillofac Surg. 2018;76:647-55.

5. Liang J, Yu T, Wang X, Zhao Y, Fang F, Zeng W, et al. Free tissue flaps in head and neck reconstruction: clinical application and analysis of 93 patients of a single institution. Braz J Otorhinolaryngol. 2018;84:416-25.

6. Lahtinen S, Koivunen P, Ala-Kokko T, Kaarela O, Ohtonen P, Laurila P, et al. Complications and outcome after free flap surgery for cancer of the head and neck. Br J Oral Maxillofac Surg. 2018;56:684-91.

7. Goh C, Kok Y, Yong C, Tan E, Goh L, Chew K, et al. Outcome predictors in elderly head and neck free flap reconstruction: a retrospective study and systematic review of the current evidence. J Plast Reconstr Aesthet Surg. 2018;71:719-28.

8. Varadarajan V, Arshad H, Dziegielewski P. Head and neck free flap reconstruction: what is the appropriate post-operative level of care? Oral Oncol. 2017;75:61-6.

9. Becker S, Menzebach M, Kuchler T, Hertrampf K, Wenz H, Wiltfang J. Quality of life in oral cancer patients--effects of mandible resection and socio-cultural aspects. J Craniomaxillofac Surg. 2012;40:24-7.

10. Lopez-Jornet P, Camacho-Alonso F, Lopez-Tortosa J, Palazon Tovar T, Rodriguez-Gonzales M. Assessing quality of life in patients with head and neck cancer in Spain by means of EORTC QLQ-C30 and QLQH\&N35. J Craniomaxillofac Surg. 2012;40:614-20.

11. Yu P, Chang D, Miller M, Reece G, Robb G. Analysis of 49 cases of flap compromise in 1310 free flaps for head and neck reconstruction. Head Neck. 2009;31:45-51.

12. Haughey B, Wilson E, Kluwe L, Piccirillo J, Fredrickson J, Sessions D, et al. Free flap reconstruction of the head and neck: analysis of 241 cases. Otolaryngol Head Neck Surg. 2001;125:10-7.

13. Pohlenz P, Klatt J, Schon G, Blessmann M, Li L, Schmelzle R. Microvascular free flaps in head and neck surgery: complications and outcome of 1000 flaps. Int J Oral Maxillofac Surg. 2012;41:739-43.

14. Casal D, Carmo L, Melancia T, Zagalo C, Cid O, Rosa-Santos J. Lip cancer: a 5-year review in a tertiary referral centre. J Plast Reconstr Aesthet Surg. 2010;63:2040-5.

15. Moniz P, Casal D, Rosa J. Nasolabial skin cancer recurrence and incomplete excision: a five year review. Skin Cancer. 2010;25:43-57.

16. Rosa J, Casal D, Moniz P. Upper eyelid reconstruction with a horizontal $\mathrm{V}$-Y myotarsocutaneous advancement flap. J Plast Reconstr Aesthet Surg. 2010;63:2013-7.

17. Carvalho R, Casal D, Zagalo C, Rosa J. Radix nasi transposition flap for medial canthus and nasal sidewall defects. Dermatol Surg. 2011;37:1777-80.

18. Cunha T, Melancia T, Zagalo C, Brito J, Miguel S, Casal D. Risk factors for surgical site infection in cervico-facial oncological surgery. J Craniomaxillofac Surg. 2012;40:443-8.

19. Ettinger K, Yetzer J. Controversies in Oral and Maxillofacial Oncology. Oral Maxillofac Surg Clin North Am. 2017;29:487-501.

20. Van Genechten M, Batstone M. The relative survival of composite free flaps in head and neck reconstruction. Int J Oral Maxillofac Surg. 2016;45:163-6.

21. Alfouzan AF. Review of surgical resection and reconstruction in head and neck cancer. Traditional versus current concepts. Saudi Med J. 2018;39:971-80.

22. Pohlenz P, Blessmann M, Heiland M, Blake F, Schmelzle R, Li L. Postoperative complications in 202 cases of microvascular head and neck reconstruction. J Craniomaxillofac Surg. 2007;35:311-5.

23. Eckardt A, Meyer A, Laas U, Hausamen J. Reconstruction of defects in the head and neck with free flaps: 20 years experience. $\mathrm{Br} \mathrm{J}$ Oral Maxillofac Surg. 2007;45:11-5.

24. Grammatica A, Piazza C, Pellini R, Montalto N, Lancini D, Vural A, et al. Free flaps for advanced oral cancer in the "Older Old" and "Oldest Old": a retrospective multi-institutional study. Front Oncol. 2019;9:604.
25. Grammatica A, Piazza C, Paderno A, Taglietti V, Marengoni A, Nicolai $P$. Free flaps in head and neck reconstruction after oncologic surgery: expected outcomes in the elderly. Otolaryngol Head Neck Surg. 2015;152:796-802.

26. Wester J, Lindau R, Wax M. Efficacy of free flap reconstruction of the head and neck in patients 90 years and older. JAMA Otolaryngol Head Neck Surg. 2013;139:49-53.

27. Herle P, Shukla L, Morrison W, Shayan R. Preoperative radiation and free flap outcomes for head and neck reconstruction: a systematic review and meta-analysis. ANZ J Surg. 2015;85:121-7.

28. Eskander A, Kang S, Tweel B, Sitapara J, Old M, Ozer E, et al. Predictors of complications in patients receiving head and neck free flap reconstructive procedures. Otolaryngol Head Neck Surg. 2018;158:83947.

29. Reis J, Amarante J, Malheiro E, Santa-Comba A, Costa-Ferreira A, Barroso M. Retalhos livres na reconstrução da cabeca e pescoco. Experiência clinica. Acta Med Port. 1998;11:103-10.

30. Costa H, Zenha H, Sequeira H, Coelho G, Gomes N, Pinto C, et al. Microsurgical reconstruction of the maxilla: algorithm and concepts. J Plast Reconstr Aesthet Surg. 2015;68:e89-104.

31. Horta R, Nascimento R, Silva A, Amarante J. The retromolar trigone: anatomy, cancer treatment modalities, reconstruction, and a classification system. J Craniofac Surg. 2016;27:1070-6.

32. Neto T, Horta R, Balhau R, Coelho L, Silva P, Correia-Sá I, et al. Resection and microvascular reconstruction of bisphosphonate-related osteonecrosis of the jaw: The role of microvascular reconstruction. Head Neck. 2016;38:1278-85.

33. Horta R, Costa J, Valenca-Filipe R, Amarante J. ALT chimeric flap associated to a dura mater biomatrix substitute for severe desfigurative mandible osteoradionecrosis and deficient bone consolidation after a free fibula flap. Br J Oral Maxillofac Surg. 2014;52:670-2.

34. Horta R, Valenca-Filipe R, Monteiro D, Silva A, Amarante J. Chimeric flaps and "their variations": different options for immediate reconstruction of massive facial defects. Facial Plast Surg. 2014;30:578-80.

35. Tevis SE, Kennedy GD. Postoperative complications and implications on patient-centered outcomes. J Surg Res. 2013;181:106-13.

36. Deschler D, Moore M, Smith R. Quick reference guide to TNM staging of head and neck cancer and neck dissection classification. $4^{\text {th }}$ ed. Old Town Alexandria: American Academy of Otolaryngology-Head Neck Surgery Foundation; 2014.

37. World Medical Association. Declaration of Helsinki: ethical principles for medical research involving human subjects. JAMA. 2013;310:2191-4.

38. Dawson A, Lignou S, Siriwardhana C, O'Mathuna DP. Why research ethics should add retrospective review. BMC Med Ethics. 2019;20:68.

39. Walker D, Smith T. Logistic regression under sparse data conditions. $J$ Mod Appl Stat Methods.. 2020;18:25

40. Kruse A, Bredell M, Lubbers H, Jacobsen C, Gratz K, Obwegeser J. Clinical reliability of radial forearm free-flap procedure in reconstructive head and neck surgery. J Craniofac Surg. 2011;22:822-5.

41. Gerressen M, Pastaschek C, Riediger D, Hilgers R, Hölzle F, Noroozi N, et al. Microsurgical free flap reconstructions of head and neck region in 406 cases: a 13-year experience. J Oral Maxillofac Surg. 2013;71:62835.

42. Eckardt A, Fokas K. Microsurgical reconstruction in the head and neck region: an 18-year experience with 500 consecutive cases. J Craniomaxillofac Surg. 2003;31:197-201.

43. Hanken H, Wilkens R, Riecke B, Al-Dam A, Tribius S, Kluwe L, et al. Is immediate bony microsurgical reconstruction after head and neck tumor ablation associated with a higher rate of local recurrence? J Craniomaxillofac Surg. 2015;43:373-5.

44. Pabst A, Thiem D, Goetze E, Bartella A, Neuhaus M, Hoffmann J, et al How is neck dissection performed in Oral and Maxillofacial Surgery? Results of a representative nationwide survey among university and non-university hospitals in Germany. Clin Oral Investig. 2021;25:300719.

45. Shah JP. Neck dissection: which and when? ANZ J Surg. 1994;64:225.

46. Capote A, Escorial V, Muñoz-Guerra M, Rodríguez-Campo F, Gamallo C, Naval L. Elective neck dissection in early-stage oral squamous cell carcinoma--does it influence recurrence and survival? Head Neck. 2007;29:3-11.

47. Wu H, Liu F, Ji F, Guo M, Wang Y, Cao M. Identification of independent risk factors for complications: a retrospective analysis of 163 fibular free flaps for mandibulofacial reconstruction. J Oral Maxillofac Surg. 2018;76:1571-7 
48. Cannady S, Hatten K, Wax M. Postoperative controversies in the management of free flap surgery in the head and neck. Facial Plast Surg Clin North Am. 2016;24:309-14.

49. Zhou W, Zhang W, Yu Y, Wang Y, Mao C, Guo C, et al. Risk factors for free flap failure: a retrospective analysis of 881 free flaps for head and neck defect reconstruction. Int J Oral Maxillofac Surg. 2017;46:941-5.

50. Nao E, Dassonville O, Chamorey E, Poissonnet G, Pierre C, Riss J, et al. Head and neck free-flap reconstruction in the elderly. Eur Ann Otorhinolaryngol Head Neck Dis. 2011;128:47-51.

51. Bozikov K, Arnez Z. Factors predicting free flap complications in head and neck reconstruction. J Plast Reconstr Aesthet Surg. 2006;59:73742.

52. Lydiatt W, O'Sullivan B, Patel S. Major changes in head and neck staging for 2018. Am Soc Clin Oncol Educ Book. 2018;38:505-14

53. Colevas A, Yom S, Pfister D, Spencer S, Adelstein D, Adkins D, et al. NCCN Guidelines Insights: head and neck cancers, Version 1. 2018. J Natl Compr Canc Netw. 2018;16:479-90.

54. Rivera C. Essentials of oral cancer. Int J Clin Exp Pathol. 2015;8:11884-
94.

55. Steele T, Meyers A. Early detection of premalignant lesions and oral cancer. Otolaryngol Clin North Am. 2011;44:221-9, vii.

56. Kamat M, Rai B, Puranik R, Datar U. A comprehensive review of surgical margin in oral squamous cell carcinoma highlighting the significance of tumor-free surgical margins. J Cancer Res Ther. 2019;15:449-54.

57. Shuman AG. Contemplating resectability. Hastings Cent Rep. 2017;47:34.

58. Mehanna H, Kong A, Ahmed S. Recurrent head and neck cancer: United Kingdom National Multidisciplinary Guidelines. J Laryngol Otol. 2016;130:S181-90.

59. Catanzaro S, Copelli C, Manfuso A, Tewfik K, Pederneschi N, Cassano $\mathrm{L}$, et al. Intraoperative navigation in complex head and neck resections: indications and limits. Int J Comput Assist Radiol Surg. 2017;12:881-7.

60. Chen K, Kuo S, Chien P, Hsieh H, Hsieh C. Comparison of the surgical outcomes of free flap reconstruction for primary and recurrent head and neck cancers: a case-controlled propensity score-matched study of 1,791 free flap reconstructions. Sci Rep. 2021;11:2350. 